\title{
The consumption of antithrombin III during coagulation, its consequences for the calculation of prothombinase activity and the standardisation of heparin activity
}

Citation for published version (APA):

Beguin, S., Kessels, H., Dol, F., \& Hemker, H. C. (1992). The consumption of antithrombin III during coagulation, its consequences for the calculation of prothombinase activity and the standardisation of heparin activity. Thrombosis and Haemostasis, 68(2), 136-142. https://doi.org/10.1055/s-0038-1656338

Document status and date:

Published: 01/01/1992

DOI:

10.1055/s-0038-1656338

Document Version:

Publisher's PDF, also known as Version of record

Please check the document version of this publication:

- A submitted manuscript is the version of the article upon submission and before peer-review. There can be important differences between the submitted version and the official published version of record. People interested in the research are advised to contact the author for the final version of the publication, or visit the DOI to the publisher's website.

- The final author version and the galley proof are versions of the publication after peer review.

- The final published version features the final layout of the paper including the volume, issue and page numbers.

Link to publication

\footnotetext{
General rights rights.

- You may freely distribute the URL identifying the publication in the public portal. please follow below link for the End User Agreement:

www.umlib.nl/taverne-license

Take down policy

If you believe that this document breaches copyright please contact us at:

repository@maastrichtuniversity.nl

providing details and we will investigate your claim.
}

Copyright and moral rights for the publications made accessible in the public portal are retained by the authors and/or other copyright owners and it is a condition of accessing publications that users recognise and abide by the legal requirements associated with these

- Users may download and print one copy of any publication from the public portal for the purpose of private study or research.

- You may not further distribute the material or use it for any profit-making activity or commercial gain

If the publication is distributed under the terms of Article $25 \mathrm{fa}$ of the Dutch Copyright Act, indicated by the "Taverne" license above, 


\title{
The Consumption of Antithrombin III During Coagulation, Its Consequences for the Calculation of Prothrombinase Activity and the Standardisation of Heparin Activity
}

\author{
S. Béguin, H. Kessels, F. Dol ${ }^{1}$, and H. C. Hemker \\ From the Department of Biochemistry and Cardiovascular Research Institute at the Rijksuniversiteit \\ Limburg, Maastricht, The Netherlands and ${ }^{1}$ Hôpital Purpan, Lab. d’Hémostase, Toulouse, France
}

\section{Summary}

The decay rate of thrombin in plasma is shown to be linearly proportional to the concentration of antithrombin III (AT III), not only in the absence but also in the presence of heparin. This is a consequence of partitioning of heparin between AT III and other plasma proteins.

In previous articles we calculated the prothrombin converting activity assuming a fixed concentration of AT III. Since AT III is consumed during the clotting process, prothrombinase activity is more accurately approximated using an algorithm that counts with the decrease of the AT III concentration. It is shown this leads to higher prothrombinase activities. The (absence of) inhibition of prothrombin conversion by prothrombinase in the presence of heparins found with the previous method is also found using the new algorithm.

From the results presented it is evident that characteristic parameters of heparin action have to be normalised to the AT III concentration. On this basis we define a Standard Independent Unit of the antithrombin activity of heparin.

\section{Introduction}

The understanding of the action of heparins in plasma requires a detailed analysis of the influence of heparin on thrombin decay. We have previously described how we determined the pseudo first-order decay constant $\left(k_{\mathrm{dec}}\right)$ of endogeneously generated thrombin in plasma, in the absence and in the presence of heparins. In the course of the thrombin generation process we stopped prothrombin conversion via inhibition of factor $\mathrm{Xa}$ with soybean trypsin inhibitor and determined the velocity of decay of the remaining thrombin $(1,2)$. We showed that the global decay constant thus obtained is the sum of the decay constant $\left(k_{2}\right)$ caused by $\alpha_{2}$-macroglobulin $\left(\alpha_{2} \mathrm{M}\right)$ and an $\alpha_{2} \mathrm{M}$-independent decay constant $\left(k_{1}\right)$. The latter consists of an AT III-independent part $(\sim 10 \%)$ and an AT III-dependent part $(\sim 90 \%)$. The AT IIIindependent part is caused by various inhibitors, mainly by $\alpha_{1}$ antitrypsin (1), but not by heparin cofactor II (HC II) because, at heparin concentrations $<2 \mathrm{U} / \mathrm{ml}$, as used in this article, the stimulation of HC II is negligible (3). We therefore can describe the increase of thrombin decay brought about by the addition of heparin in terms of the acceleration of AT III dependent inactivation.

The level of AT III antigen in serum is significantly smaller than the initial plasma level $(4,5)$ because AT III is consumed during the coagulation process. In this article we wanted to investigate in detail whether the decrease of AT III during the

Correspondence to: Dr. S. Béguin, Dept. of Biochemistry, Rijksuniversiteit Limburg, P. O. Box 616, 6200 MD Maastricht, The Netherlands coagulation process does affect the decay constant of thrombin in the presence of heparin.

The answer is not obvious a priori. In previous work we observed no variation of $k_{\mathrm{dec}}$ between 4 and $7 \mathrm{~min}$ after the start of thrombin generation, i. e. after the thrombin peak concentration has occurred. In the absence of heparin one might expect $k_{1}$ to decrease proportionally with the AT III concentration during the coagulation process since $k_{1}$ is the product of a second order decay constant $k_{1}$ ' and the AT III concentration. In the presence of heparin the question is more complicated. The $2 \mu \mathrm{M}$ of AT III present in plasma represent a large molar excess over $1 \mathrm{U} / \mathrm{ml}$ of heparin $(1 \mathrm{U} / \mathrm{ml} \approx 110 \mathrm{nM}$ AT III binding standard heparin). The heparin-catalysed interaction of AT III and thrombin was shown to be saturable with respect to both AT III and thrombin and the apparent dissociation constant of the functional AT IIIheparin complex is $\sim 160 \mathrm{nM}(6-10)$. This means that the normal plasma level of AT III could be expected to bind virtually all heparin up to $1 \mathrm{U} / \mathrm{ml}$ and even higher. The rate of thrombin inactivation then should be proportional to the concentration of heparin only, and not depend any more on the AT III concentration.

In plasma, however, other heparin binding proteins may compete for heparin. The outcome of this competition is dependent upon the affinity constants and concentrations of all heparin binding proteins and no reasonable guess can be made on the influence of AT III concentration on $k_{\mathrm{dec}}$. Therefore we reinvestigated in detail the course of $k_{\text {dec }}$ during the coagulation process and its dependence on AT III and heparin concentration.

\section{Materials and Methods}

\section{Chemicals}

The chromogenic substrate for thrombin was H.D-Phe-Pip-Arg-pNA (S2238) from Kabi, Sweden. The 4th International heparin standard (4th I.S.H.) was from the National Institute for Biological Standards and Control. Reptilase was obtained from Laboratoires Stago (Asnières, France), a solution was made according to the instructions of the manufacturer. Soybean trypsin inhibitor (batch No.43 F-800) was obtained from Sigma (St. Louis, MO).

\section{Blood and Products}

Blood from 10 healthy donors was collected on $0.13 \mathrm{M}$ trisodium citrate; nine parts of blood to one part of citrate solution.

Platelet poor plasma (PPP) was obtained after two centrifugations at $900 \times \mathrm{g}, 15^{\circ} \mathrm{C}$ for $15 \mathrm{~min}$ and a third centrifugation at $23,000 \times \mathrm{g}, 4^{\circ} \mathrm{C}$, for $1 \mathrm{~h}$. PPP was pooled and stored at $-80^{\circ} \mathrm{C}$. It was checked that the clotting factors and the antiproteases were in the normal range.

Defibrinated plasma was obtained by mixing an aliquot of plasma with 1:50 volume of a reptilase solution, letting a clot form for $5 \mathrm{~min}$ at $37^{\circ} \mathrm{C}$ and keeping the clotted plasma at $0^{\circ} \mathrm{C}$ for $10 \mathrm{~min}$. The fibrin clot formed was discarded by winding it on a small plastic spatula. The concentration 


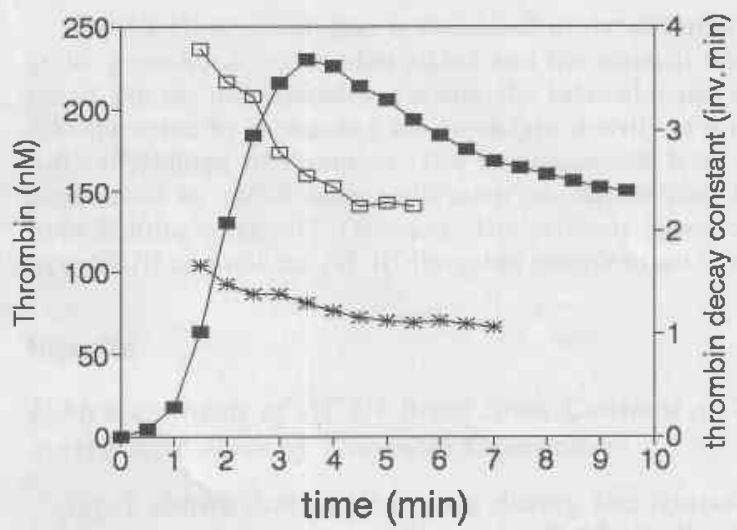

Fig. 1 The course of the endogenous thrombin decay constant during the thrombin generation test. The total constant $\left(k_{1}+k_{2}+k_{3}\right)$ is given, as obtained after inhibiting thrombin generation by addition of SBTI (16.5 $\mu \mathrm{M}$ final concentration). $\mathrm{T}$ Thrombin generation test in normal plasma. ${ }^{*} k_{\text {dec }}$ in normal plasma. $\square$ Idem with $0.03 \mathrm{U} / \mathrm{ml}$ heparin

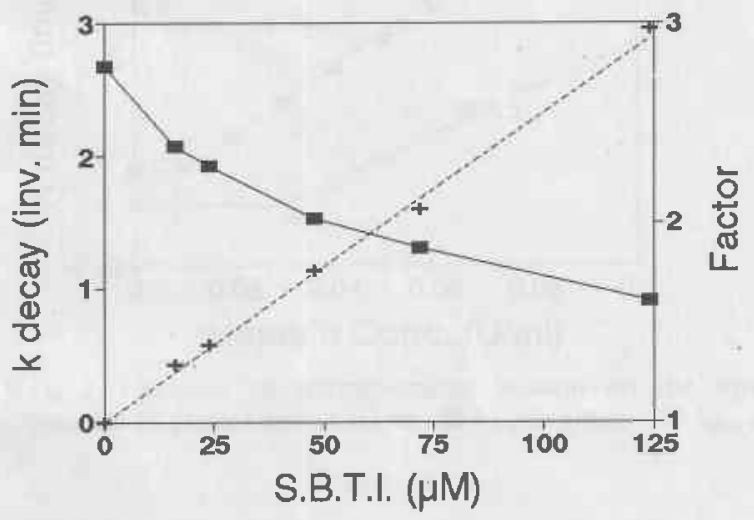

Fig. 2 Influence of SBTI on the thrombin decay constant in plasma. $k_{\mathrm{dec}}$ (left ordinate); + ratio $k_{\mathrm{dec}}$ with SBTI $/ k_{\mathrm{dec}}$ without SBTI (right ordinate)

Table 1 The influence of SBTI on thrombin decay

\begin{tabular}{llll}
\hline & No SBTI & SBTI & Ratio \\
\hline Plasma & $2.77(15.0)$ & $2.08(20.1)$ & 1.33 \\
Plasma $+0.04 \mathrm{U} / \mathrm{ml}$ hep. & $4.67(9.1)$ & $3.47(11.9)$ & 1.33 \\
Plasma $+1.25 \mu \mathrm{g} / \mathrm{ml}$ DS & $4.16(10)$ & $3.12(13.3)$ & 1.33 \\
Serum & $1.63(25.5)$ & $1.19(35.3)$ & 1.37 \\
Serum $+0.1 \mathrm{U} / \mathrm{ml}$ hep. & $3.76(11.1)$ & $2.83(14.7)$ & 1.32 \\
\hline
\end{tabular}

The total decay constant $\left(k_{1}+k_{2}\right)$ is given in $\min ^{-1}$, in brackets the half life times in s. DS = dermatan sulfate.

of factors II, VII, VIII, IX, X, XI and XII did not significantly change by the reptilase treatment (1).

Serum is the material left after plasma has been activated as in a thrombin generation test (sce below).

\section{Euglobulin Fraction}

The euglobulin fraction is obtained from defibrinated pooled plasma by acid precipitation ( $\mathrm{pH} \mathrm{5.2)} \mathrm{at} \mathrm{low} \mathrm{ionic} \mathrm{strength} \mathrm{as} \mathrm{described} \mathrm{in} \mathrm{Josso}$ and Prou-Wartelle (11). The precipitate is collected by centrifugation and dissolved in half the initial plasma volume of $21.6 \mathrm{mM}$ trisodium citrate in buffer $\mathrm{A}$. In order to obtain thrombin, thrombin generation is triggered by adding 0.25 vol of diluted human brain thromboplastin in $100 \mathrm{mM}$ of $\mathrm{CaCl}_{2}$ to 1 vol of euglobulin fraction.

Human brain thromboplastin was prepared according to Owren and Aas (12).

\section{Determination of Thrombin Generation in Plasme}

To $240 \mu \mathrm{l}$ of defibrinated plasma are added $60 \mu \mathrm{l}$ of $50 \mathrm{mM}$ Tris- $\mathrm{HCl}$, $100 \mathrm{mM} \mathrm{NaCl}, 0.5 \mathrm{mg} / \mathrm{ml}$ ovalbumin, $\mathrm{pH} 7.35$ (buffer A), containing heparin at the desired concentration. Thrombin formation is started by the addition of $60 \mu \mathrm{l}$ of a solution containing $100 \mathrm{mM}$ of $\mathrm{CaCl}_{2}$ and human brain thromboplastin, diluted so as to clot the uninhibited, non-defibrinated reaction mixture in $70 \mathrm{~s}$ (final dilution $\sim 1: 240$ ). At intervals a $10 \mu 1$ aliquot of the mixture is sampled into a disposable plastic cuvette containing $465 \mu \mathrm{l}$ of $50 \mathrm{mM}$ Tris- $\mathrm{HCl}, 100 \mathrm{mM} \mathrm{NaCl}, 20 \mathrm{mM}$ EDTA, $0.5 \mathrm{mg}$ ovalbumin/ml, pH 7.90 (buffer B) and $25 \mu \mathrm{l}$ of $\mathrm{S} 2238(4 \mathrm{mM})$ and prewarmed for at least $5 \mathrm{~min}$ at $37^{\circ} \mathrm{C}$. After about $120 \mathrm{~s}$ the reaction in the cuvette is stopped by adding $300 \mu \mathrm{l}$ of concentrated acetic acid. The precise moments of sampling and stopping were recorded on a personal computer by means of pushbutton equipped pipettes. Optical densities are read at $405 \mathrm{~nm}$ in a dual wavelength $(405 \mathrm{~nm}-536 \mathrm{~nm})$ dedicated instrument constructed in our workshop. From the optical density and the start and stop times, the amidolytic activities $(\mathrm{mOD} / \mathrm{min})$ were calculated. The amidolytic activity is the result of a) free thrombin and b) $\alpha_{2}$ macroglobulin bound thrombin $\left(\alpha_{2} \mathrm{M}-\mathrm{T}\right)$. At the end of the coagulation process a stable endlevel of amidolytic activity is obtained, due to the $\alpha_{2} \mathrm{M}-\mathrm{T}$ complex formed. $k_{2}$ in our batch of normal plasma, determined according to Hemker et al. (1), equalled $0.23 \mathrm{~min}^{-1}$ and was independent of the heparin concentration.

\section{The Pseudo First Order Rate Constant of Thrombin Inactivation}

Endogenous thrombin. Defibrinated plasma $(120 \mu \mathrm{l})$ was incubated with $14 \mu \mathrm{l}$ of buffer A. Thrombin generation was started as described in the previous section. At a timepoint when the concentration of thrombin was sufficiently high, $6 \mu \mathrm{l}$ of Soybean Trypsin Inhibitor (SBTI) solution $(10 \mathrm{mg} / \mathrm{ml})$ and $10 \mu \mathrm{l}$ of buffer containing the required amount of heparin were added. SBTI at this concentration was shown to block the activity of prothrombinase completely and instantaneously and not to influence the activity of thrombin on chromogenic substrate (1). At suitable time intervals (2-10 s) after addition of the SBTI solution, $10 \mu \mathrm{I}$ aliquots were drawn for measurement of thrombin concentrations, as described above.

Exogenous thrombin. A mixture of $120 \mu 1$ of defibrinated human plasma and $40 \mu 1$ of buffer A with or without heparin was prewarmed for $2 \mathrm{~min}$ at $37^{\circ} \mathrm{C}$, then $20 \mu \mathrm{l}$ of a thrombin preparation were added to so as to obtain a final concentration of $100 \mathrm{nM}$. The disappearance of thrombin was then measured as described above.

In order to approach the experimental conditions of endogenous thrombin decay as closely as possible, we have not used purified thrombin but thrombin that was freshly generated either in a euglobulin fraction (see above) or in plasma (same conditions as in the thrombin generation experiments).

In both methods the amidolytic activities $\left(C_{t}\right)$ as obtained in the experiment, were fitted to the three parameter curve $C_{t}=C_{\infty}+\left(C_{0}-\right.$ $C_{\infty}$ ) $\mathrm{e}^{-k t}$, where $k=k_{\mathrm{dec}}=k_{1}+k_{2}$ (see introduction). $C_{0}$ is the initial amidolytic activity. $C_{\infty}$ is the residual, steady end-level activity due to the $\alpha_{2} \mathrm{M}-\mathrm{T}$ complex. In our hands, the standard error of a single estimation is below $7 \%$ as long as half life times exceed $4 \mathrm{~s}\left(k_{\mathrm{dec}}=10 \mathrm{~min}^{-1}\right)$. At shorter half life times it increases proportionally with $k_{\text {dec }}$, with about $1 \%$ per $\min ^{-1}$.

\section{Determination of AT III in Plasma and in Serum}

The functional assay is essentially the titration of an unknown amount of AT III with a known, excess amount of thrombin. $100 \mu \mathrm{l}$ of a suitable dilution of the sample (1:100 to $1: 800)$ in buffer B containing $2 \mathrm{U} / \mathrm{ml}$ standard heparin, with $100 \mu \mathrm{l}$ of a $20 \mathrm{nM}$ thrombin solution were incubated at $37^{\circ} \mathrm{C}$ in a plastic spectrophotometer cuvette during $10 \mathrm{~min}$. Then $300 \mu \mathrm{l}$ of $330 \mu \mathrm{M}$ S2238 in buffer B were added, and the residual thrombin induced amidolytic activity was measured at $405 \mathrm{nM}$ in a spectrophotometer thermostated at $37^{\circ} \mathrm{C}$. This amidolytic activity was converted into $\mathrm{nM}$ thrombin via a reference curve obtained with active site titrated thrombin. 
The AT III concentration is calculated as the difference between the initial thrombin concentration added and the residual thrombin activity found. For the measurement in serum, the value obtained is corrected for $\alpha_{2} \mathrm{M}$-thrombin by subtracting the amidolytic activity of serum, measured without addition of thrombin. The immunological level of AT III was determined by radial immunodiffusion on commercial diffusion plates from Behringwerke AG, Germany. The antibody appeared to recognise free AT III and not the AT III-thrombin complex (see Discussion).

\section{Results}

\section{Measurements of AT III Breakdown Constant of Thrombin during the Course of Thrombin Generation}

Fig. 1 shows that $k_{1}$ decreases during the course of thrombin generation. The presence of heparin $(0.03 \mathrm{U} / \mathrm{ml})$ added together

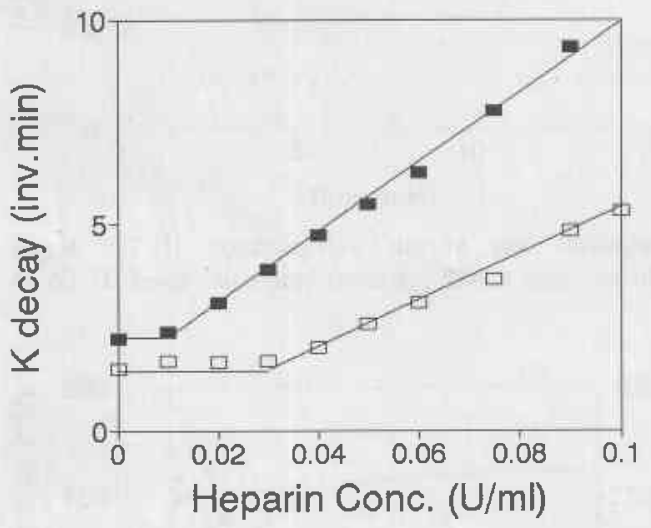

Fig. 3 Influence of unfractionated heparin on the thrombin decay constant in plasma and in serum. $\square k_{\text {dec }}$ in plasma; $\square k_{\text {dec }}$ in serum

Table 2 Comparison of AT III determinations in plasma and in serum

\begin{tabular}{lccc}
\hline Method & Plasma & Serum & Ratio \\
\hline Antigenic AT III $(\%)$ & $112 \pm 13$ & $69 \pm 8$ & 1.62 \\
Functional AT III $(\mu \mathrm{M})$ & $2.24 \pm 0.11$ & $1.49 \pm 0.07$ & 1.50 \\
$k_{1}=k_{1}$ '[AT III] $\left(\mathrm{min}^{-1}\right)$ & $3.379 \pm 0.246$ & $2.274 \pm 0.090$ & 1.49 \\
$k_{1} /\left[\mathrm{AT} \mathrm{III]}=k_{1}\left(\mathrm{~min}^{-1} / \mu \mathrm{M}\right)\right.$ & 1.508 & 1.522 & 0.99 \\
\hline
\end{tabular}

The antigenic AT III values are obtained in 33 individual plasmas from normal volunteers and expressed as \% of the "normal plasma" that accompanied the plates. The functional AT III and $k_{1}$ ' values were obtained in normal pool plasma (mean of 12 experiments) and corrected for the $2: 3$ dilution in the experimental system.

Table 3 Comparison of old and new calculations

\begin{tabular}{lrrlr}
\hline Hep] & $\begin{array}{l}\text { [Ha] } \\
(\mathrm{U} / \mathrm{ml})\end{array}$ & $\begin{array}{l}\text { Inhibition } \\
\text { (nM) }\end{array}$ & \multicolumn{1}{c}{$\begin{array}{l}\text { Prothrombinase } \\
(\mathrm{nM} / \mathrm{min})\end{array}$} & $\begin{array}{l}\text { Inhibition } \\
\%\end{array}$ \\
\hline A & & & & \\
0.00 & 147.90 & 0.00 & 341.58 & 0.00 \\
0.02 & 119.50 & 19.20 & 309.57 & 9.40 \\
0.03 & 90.30 & 38.90 & 319.18 & 6.60 \\
0.04 & 79.00 & 46.60 & 333.77 & 2.30 \\
0.05 & 58.10 & 60.70 & 350.47 & -2.50 \\
B & & & & 0.00 \\
0.00 & 143.00 & 0.00 & 234.20 & 10.70 \\
0.02 & 115.30 & 19.40 & 209.01 & 8.00 \\
0.03 & 87.40 & 38.90 & 215.54 & -0.40 \\
0.04 & 76.40 & 46.60 & 235.09 & 7.20 \\
0.05 & 56.07 & 60.80 & 217.32 & \\
\hline
\end{tabular}

Prothrombinase activities calculated A) counting with AT III consumption, and B) using pseudo first order AT III dependent decay constants. with the SBTI increases the decay constants found but the decrease in the course of the experiment remains. Only a small change is observed after the peak of the curve, in contrast to the first minutes of the test, when the constant decreases rapidly. This explains why we considered the decay constant not to vary on basis of previous experiments carried out after the peak only (1). The experiments carried out on endogenous thrombin require a sufficient amount of thrombin to be generated. They cannot be performed in plasma or during the first minute of a thrombin generation test, nor in serum or during the last minutes. In order to obtain data on plasma and serum one has to add exogenous thrombin. Because we wanted to remain as close as possible to endogenously generated thrombin we prepared thrombin by recalcification of the euglobulin fraction of plasma, a crude fraction containing all the clotting factors but none of the inhibitors (11).

\section{Comparison of the AT III Constant of Exogenous or (Endogenous) Native Thrombin}

Before using the euglobulin thrombin preparation it was necessary to compare the decay constant of this exogenous thrombin to that of native thrombin generated during the test. To this end we compared the decay constant of euglobulin-thrombin to that of the thrombin generated in defibrinated plasma and added to non-triggered defibrinated plasma. No significant difference was found between the two values: the half life time of euglobulin-thrombin under these conditions is $15.4 \pm 0.4 \mathrm{~s}$, that of thrombin added from triggered plasma is $15.1 \pm 0.4 \mathrm{~s}$. The corresponding overall decay constants $\left(k_{\mathrm{dec}}=k_{1}+k_{2}\right)$ are resp. $2.699 \pm 0.065 \mathrm{~min}^{-1}$ and $2.784 \pm 0.073 \mathrm{~min}^{-1}(n=8)$. These values are not corrected for the $2: 3$ dilution of plasma in our experimental system.

\section{Soybean Trypsin Inhibitor and Thrombin Breakdown}

Using exogenous thrombin we have measured $k_{1}$ in serum. It turned out to be significantly higher than was to be expected from previous values obtained near the end of the thrombin generation curve $(1,2)$. It appears (Table 1), that the presence of SBTI $(16 \mu \mathrm{M})$ decreases $k_{\text {dec }}$ by a factor 1.33 , both in plasma and in serum, in the presence and in the absence of heparin and of dermatan sulfate.

As can be seen in Fig. 2 the effect of SB'TI on the thrombin breakdown constant increases with the SBTI concentration. The ratio of $k_{\mathrm{dec}}$ in the presence and in the absence of SBTI varies linearly with the SBTI concentration. This is compatible with a reversible binding between SBTI and thrombin with an apparent $K_{\mathrm{d}}$ of $\sim 70 \mu \mathrm{M}$. The difference between $k_{\mathrm{dec}}$ of endogenous and of exogenous thrombin therefore appears to be explained by the addition of SBTI necessary for the inhibition of prothrombin conversion if the decay of endogenous thrombin is to be measured.

\section{The Thrombin Breakdown Constant in Plasma and in Serum in the Absence and in the Presence of Heparin}

The AT III-dependent decay constant of thrombin in normal undiluted plasma is 1.5 times higher than that in the corresponding serum (Table 2). Both in plasma and in serum we observed (Fig. 3) that low concentrations of heparin do not influence the decay constant. The threshold is at $0.01 \mathrm{U} / \mathrm{ml}$ in plasma and at $0.04 \mathrm{U} / \mathrm{ml}$ in serum (see also discussion). Above the threshold value $k_{\mathrm{dec}}$ depends linearly on the heparin concentration. The slope of these lines describes the dependency of $k_{1}$ on the heparin concentration. In plasma this is $79.5 \mathrm{~min}^{-1}$ per I. U. of heparin $/ \mathrm{ml}$ 
Table 4 Specific activities of various heparins

\begin{tabular}{lr}
\hline & Total \\
\hline Standard heparin & 13.65 \\
Calciparin & 10.33 \\
Enoxaparin & 1.70 \\
Fraxiparin & 2.36 \\
LMW standard & 6.55
\end{tabular}

The specific activity values are the rate of increase of $k_{\mathrm{dec}}$ expressed in $\min ^{-1} / \mu \mathrm{M}$ AT III/( $\mu \mathrm{g} \mathrm{Hep./ml)}$.

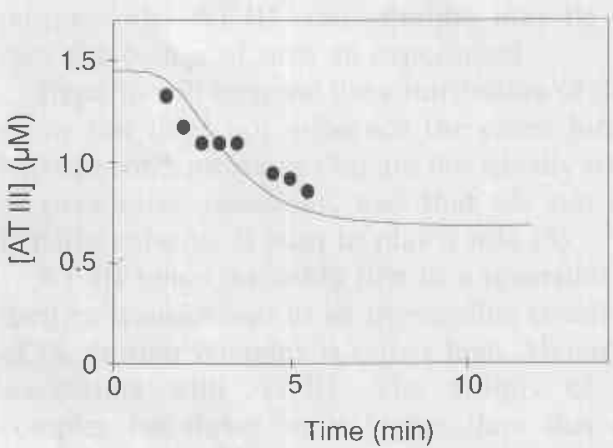

Fig. 4 AT III consumption during the thrombin generation test. - AT III level calculated from $k_{1}$; drawn line: calculated level of AT III

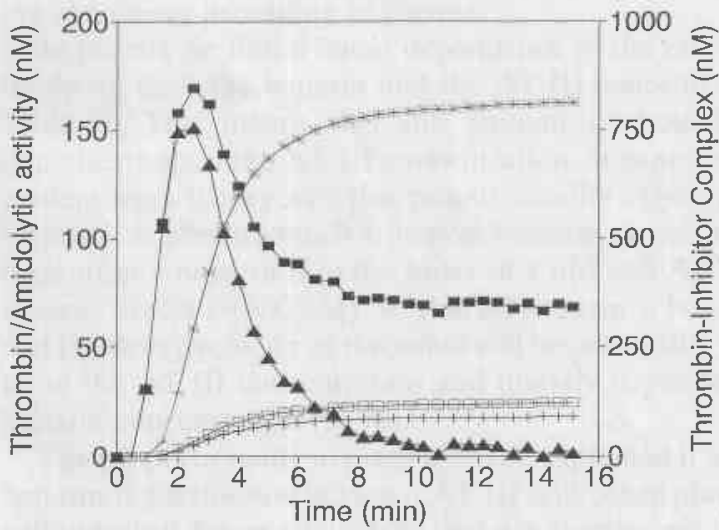

Fig. 5 A thrombin generation curve and the calculated course of different reactants. Experimental data (left scale); $\Delta$ free thrombin (calculated, left scale); + minor inhibitors-thrombin complex (calculated, right scale); $\square \alpha_{2}$ M-thrombin complex (calculated, right scale); * AT IIIthrombin complex (calculated, right scale)

or $15.44 \mathrm{~min}^{-1}$ per $\mu \mathrm{g}$ heparin/ml. In serum it is $55.9 \mathrm{~min}^{-1}$ per unit heparin $/ \mathrm{ml}$ or $10.85 \mathrm{~min}^{-1}$ per $\mu \mathrm{g}$ heparin $/ \mathrm{ml}$. Thus in serum it is about 1.5 times lower than that in plasma. This is the same ratio as between the plasma antigenic AT III level and the serum antigenic AT III-level, which, if we admit that only free AT III is revealed by the antibody (see Discussion), suggests that $k_{1}$ is proportional to both the AT III concentration and the heparin concentration. Indeed, a second order rate constant $\left(k_{1}{ }^{\prime}\right)$ i. e. $k_{1}$ expressed per $\mu \mathrm{M}$ AT III, appears to be identical in plasma and serum (Table 2).

\section{A Better Approximation of Prothrombinase Activity}

In a previous article we have shown that it is possible to obtain the course of the velocity of prothrombin conversion (i.e. the course of the prothrombinase activity) from the course of the thrombin concentration and the decay constants of thrombin (1). The reasoning behind this calculation is that the net changes of the thrombin concentration are the sum of prothrombin conversion velocity and the thrombin inactivation velocity at any moment. In these calculations we took $k_{1}$ as a constant, on the basis of the fact that we could not find a significant change between 4 and 7 min after the start of the reaction. From Fig. 4 it is clear that indeed in this time interval the changes in AT III concentration, and hence of $k_{1}$, are small. Nevertheless, over the whole of a thrombin generation experiment $k_{1}$ cannot realistically be represented by a constant. We therefore modified the calculation of the velocity of thrombin decay from $v_{\mathrm{dec}}=\left(k_{1}+k_{2}\right)[T]$ to $v_{\text {dec }}=\left(k_{1}\right.$, [AT III $\left.]+k_{2}+k_{3}\right) * T$. As in the previous calculation $[T]$ is the concentration of free thrombin at the moment of calculation, obtained from the measured amidolytic activity minus the contribution of the $\alpha_{2} \mathrm{M}$-thrombin complex. New is [AT III], i. e. the concentration of free AT III at the moment of calculation, obtained by subtracting from the initial AT III concentration the amount of AT III bound in the AT III-thrombin complex (see also Appendix). Table 3 shows a comparison of the old and the new way of calculating prothrombinase activities. Although the absolute values differ, the inhibitions brought about by heparin are comparable.

Fig. 5 depicts the course of the various reactants as calculated with the new algorithm. The course of the AT III concentration during coagulation was also calculated from the observed changes in $k_{1}$.

\section{The Second Order Decay Constant of Various Heparins}

On the basis of the observation that $k_{\mathrm{dec}}$ is proportional to both the concentration of AT III and the heparin concentration, it is a logical next step to express the antithrombin specific activity of heparin in terms of the increase of the thrombin decay constant that it causes at a normalised AT III level.

In Table 4 we show the specific antithrombin activities of several current heparins expressed as the increase of $k_{1}$ ' caused by $1 \mu \mathrm{g}$ of heparin per ml plasma normalised to an AT III level of $1 \mu \mathrm{M}$.

\section{Discussion}

At any moment during coagulation, the thrombin decay process can be described as the sum of three inactivation reactions, due to a) AT III, b) $\alpha_{2} \mathrm{M}$, and c) $\alpha_{1}$-antitrypsin and miscellaneous minor inhibitors. The rate of decay for each of these reactions is given by the product of the thrombin concentration, the inhibitor concentration and the second-order rate constant for the reaction. The concentrations of $\alpha_{2} \mathrm{M}$ and $\alpha_{1}$ antitrypsin are so high compared to the amounts of thrombin that they bind $\left[\alpha_{2} \mathrm{M}: 3.5 \mu \mathrm{M}\right.$ inhibiting $<0.40 \mu \mathrm{M}$ thrombin; $\alpha_{1}$ antitrypsin: $25 \mu \mathrm{M}$ inhibiting $<0.15 \mu \mathrm{M}$ thrombin (1)], that they may be considered as constant over the course of a thrombin generation experiment. These reactions thus follow pseudo firstorder kinetics with a first-order rate constant equal to the product of the inhibitor concentration and the second-order rate constant.

This is not the case for AT III, however. In normal plasma about two thirds of the total amount of prothrombin converted, i. e. $\sim 1 \mu \mathrm{M}$ will end up as thrombin captured by AT III, which accounts for a decrease of AT III from $2.5 \mu \mathrm{M}$ to $1.5 \mu \mathrm{M}$ (Table 2). It is remarkable that the immunodiffusion apparently assesses free AT III only. Probably by the interaction with thrombin and/or by the interaction of the AT III-thrombin complex with vitronectin (13) the antigenic determinants of AT III are masked. 
Because of AT III consumption during coagulation, secondorder kinetics must be used for the description of the AT III dependent thrombin decay, i. e.:

$v=k_{1}$ [AT III] [IIa]

instead of

$v=k_{1}[\mathrm{Ma}]$.

The situation is different when measuring thrombin decay constants. In this type of experiment typically only $100 \mathrm{nM}$ of thrombin will be complexed to AT III so that for all practical purposes the AT III concentration may be considered constant over the course of such an experiment.

Heparin will increase the contribution of the AT III dependent decay but does not influence the other inhibitors (2). Only at heparin concentrations that are not usually reached in therapeutic or preventive situations, and that are not discussed here, will heparin cofactor II start to play a role (3).

AT III binds thrombin first in a reversible complex which can then be transformed to an irreversible covalent complex. The $K_{\mathrm{d}}$ of the former complex is rather high. Heparin acts by reversibly associating with AT III. The affinity of the heparin-AT III complex for thrombin is higher than that of AT III alone by several orders of magnitude. The rate constant for the formation of the irreversible thrombin AT III complex is not altered (14). Thus, the rate of inactivation of thrombin is proportional to the amount of antithrombin-heparin complex under the non saturating conditions prevailing in plasma.

In plasma we find a linear dependence of the rate of thrombin decay on both the heparin and the AT III concentration (Fig. 3, Table 2). This means that the amount of bound heparin is dependent upon the AT III concentration. It is not automatically evident from theory why this proportionality exists. In a purified system it is absent, which is logical because the concentration of high affinity heparin is in the order of $1 \mathrm{nM}$ and AT III is usually in large excess $(\sim 500 \mathrm{nM})$, so that all heparin is bound to AT III and the decay velocity of thrombin will be practically independent upon the AT III concentration and linearly dependent upon the heparin concentration $(9,10)$.

The proportionality in plasma can be explained if we admit that heparin is partitioned between AT III and other plasma proteins with which it forms complexes that are inactive on thrombin. In that case the amount of AT III present will determine how successfully AT III can compete with other heparin-binding plasma proteins.

Heparin is known to bind to many plasma proteins such as albumin, fibrinogen, fibronectin, lipoproteins. To histidin-rich glycoprotein (HRGP, plasma concentration $\sim 5 \mu \mathrm{M}$ ) it binds with high affinity $\left(K_{\mathrm{d}}=7 \mathrm{nM}\right)(15-17)$. We surmise that apart from HRGP there may be several more heparin binding proteins responsible for the observed proportionality of heparin dependent thrombin inhibition with the heparin concentration.

The concentration of the AT III heparin complex $(C)$ in the presence of AT III $(A)$ and one other protein $(B)$ binding heparin with a dissociation constant of $K_{\mathrm{Db}}$ is given by:

$C=H_{\text {tot }} \lambda A_{\text {tot }} /\left(\lambda A_{\text {tot }}+K_{\mathrm{Da}}\right)$

where

$\lambda=1-B_{\text {tot }} /\left(B_{\text {tot }}+K_{\mathrm{Db}}\right)$

in the case of $K_{\mathrm{Da}} \gg \lambda A_{\mathrm{tot}}$, as is true for $\operatorname{HRGP}\left(K_{\mathrm{Da}} \sim 160 \mathrm{nM}\right.$, $\lambda A_{\text {tot }} \sim 2 \mathrm{nM}$ ) equation I reduces to:

$C=H_{\text {tot }} \lambda A_{\text {tot }} / K_{\text {Da }}$

which states that $C$, and therefore the AT III dependent thrombin decay velocity, is indeed linearly proportional to the AT III concentration under the above conditions. Therefore, the interaction of heparin and HRGP alone could explain that the amount of heparin bound to AT III is dependent upon the heparin concentration as well as upon the AT III concentration. This property is not affected by the presence of more proteins binding heparin reversibly with different affinity. Note also that it follows from the above equations that the thrombin decay velocity in the presence of heparin is relatively insensitive to variability in the concentrations of other heparin binding proteins, because already for HRGP alone $B_{\text {tot }} \gg K_{\mathrm{D}}$.

The threshold phenomenon seen in Fig. 3 is most likely explained assuming that a certain low amount of heparin binds (perhaps irreversibly) to some plasma component with a much higher affinity than to AT III. The $K_{\mathrm{d}}$ must be in the subnanomolar range, but the concentration, equivalent to $0.01 \mathrm{U} / \mathrm{ml}$ heparin, should be low: $\sim 0.35 \mathrm{nM}$. It remains unexplained why during the clotting process this high affinity plasma component increases. Traces of platelet factor $4(\mathrm{pf} 4)$ might explain the phenomenon in plasma but not the increase observed in serum obtained from platelet poor plasma.

The effect of SBTI on the decay constant of thrombin is most easily explained by a reversible interaction between SBTI and thrombin. This interaction does not involve the active site since SBTI has no influence on the amidolytic activity of thrombin (data not shown). From the fact that the same effect is seen with an AT III and an HC II dependent reaction, and because SBTI is a known inhibitor of serine proteases we presume that it binds to thrombin without impairing its catalytic activity but hindering its interaction with antithrombins. Because the SBTI effect is identical in the presence and in the absence of heparin, it does not affect the conclusions of our previous work.

The proportionality of $k_{1}$ with the concentration of AT III has its consequences for the calculation of prothrombinase activity. We previously measured $k_{\mathrm{dec}}$ at 2 min after the thrombin peak, when prothrombin conversion had largely stopped but a sufficient amount of thrombin was still present. However, the AT III concentration by that time is already close to its serum concentration and $k_{\mathrm{dec}}$ is near its minimum value. $k_{\mathrm{dec}}$ is subsequently used to calculate the thrombin decay velocity for the entire thrombin generation curve. This leads to an underestimation of the thrombin breakdown velocity for all but the final part of the thrombin generation curve. Since the prothrombin converting activity is calculated as the sum of the observed rate of change of the thrombin concentration and the calculated thrombin decay velocity, it is underestimated as well. Measuring thrombin decay by addition of exogenous thrombin in non activated plasma which still contains $100 \%$ AT III, and counting with the consumption of the AT III concentration during coagulation when calculating thrombin decay rates solves this inaccuracy (cf. Annexe). As expected (Table 3 ) prothrombinase activities calculated in this way are higher. On the other hand, the relative differences between prothrombinase activities calculated for different experiments remain roughly the same. Thus, the main conclusions from our previous work involving the lack of inhibition of prothrombine conversion in the presence of heparin are not affected. It should be noted that the effect of inhibitor consumption on thrombin decay is even more pronounced in the case of heparin cofactor II/dermatan sulfate, since the concentration of $\mathrm{HC} \mathrm{II} \mathrm{is}$ about $50 \%$ of the plasma AT III concentration. Thus HC II/ dermatan sulfate dependent thrombin decay may diminish quite dramatically over the course of a thrombin generation experiment. It implicates that the only valid way to measure the effect of dermatan sulfate on thrombin breakdowns is to measure the decay of exogenously added thrombin in non activated plasma.

The modifications to the algorithm for calculating prothrombinase activities from thrombin generation curves are 
implemented in the computer programme "Thrombinoscope" (1) which can be obtained from the authors.

The main conclusion from the results presented is that both in the absence and in the presence of heparin the rate of AT III dependent thrombin decay during the course of coagulation in plasma is proportional to the amount of AT III present. This allows to define a standard independent unit of heparin (18): One standard independent unit (S.I.U.) of heparin antithrombin activity is that concentration of heparin that increases the decay constant of thrombin in plasma by one inverse minute per $\mu M$ of available AT III. Or, in other words, one S. I. U. is the concentration of heparin that increases by $1 \mathrm{~min}^{-1}$ the AT III dependent second-order decay constant of thrombin in plasma that contains $1 \mu \mathrm{M}$ of AT III. Plasmas as a rule will not contain $1 \mu \mathrm{M}$ of AT III but the results obtained with an arbitrary normal plasma can be expressed in that way by deviding the values found by the AT III content of the plasma. With this unit one can unequivocally express the specific antithrombin activity of a heparin in S.I.U. per unit weight of heparin (Table 4). We are currently performing experiments that show that anti-factor Xa activity can be treated analogously.

\section{Acknowledgements}

We would like to thank the "Broeders van de Beyaert" for their generous donations of normal plasma.

\section{REFERENCES}

1. Hemker HC, Willems GM, Béguin SA. A computer assisted method to obtain the prothrombin activation velocity in whole plasma independent of thrombin decay processes. Thromb Haemostas 1986; 56: $9-17$.

2. Béguin S, Lindhout T, Hemker HC. The mode of action of heparin in plasma. Thromb Haemostas 1988; 60: 457-62.

3. Tollefsen DM. Activation of heparin cofactor II by heparin and dermatan sulfate. N Rev Fr Hematol 1984; 26: 233-7.

4. Hensen A, Loeliger EA. Antithrombin III, its metabolism and its function in blood coagulation. Thromb Haemostas 1963; Suppl 1.

5. Fagerhol MK, Abilgaard U. Immunological studies on human antithrombin III. Influence of age, sex and use of oral anticonceptives on serum concentration. Scand J Haematol 1970; 7: 10-7.

6. Nesheim ME. A simple rate law that describes the kinetics of the heparin catalysed reaction between antithrombin III and thrombin. $\mathbf{J}$ Biol Chem 1982; 258: 14708-17.

7. Griffith MJ. Kinetics of the heparin-enhanced antithrombin IIIthrombin reaction. Evidence for a template model for the mechanism of action of heparin. J Biol Chem 1982; 257: 7360-5.

8. Griffith MJ. The heparin enhanced antithrombin III-thrombin reaction is saturable with respect to both antithrombin III and thrombin. $\mathrm{J}$ Biol Chem 1982; 257: 13899-902.

9. Schoen P, Wielders S, Petitou M, Lindhout T. The effect of sulfation on the anticoagulant and antithrombin III-binding properties of a heparin fraction with low affinity for antithrombin III. Thromb Haemostas 1990; 57: 415-23.

10. Schoen $P$, Lindhout $T$. The in situ inhibition of prothrombinase formed human $\alpha$-thrombin and meizothrombin(des fragment 1 ) by antithrombin III and heparin. J Biol Chem 1987; 262: 11268-74.

11. Josso F, Prou-Wartelle O. Exploration de l'hémostase. In: Techniques en Hématologie. Alagille D et al. (eds). Flammarion, Paris 1972; pp 101-8.

12. Owren P, Aas K. The control of dicumarol therapy and the quantitative determination of prothrombin and proconvertin. Scand $\mathbf{J}$ Clin Lab Invest 1951; 3: 201-18.

13. Preissner KT, Jenne D. Structure of vitronectin and its biological role in haemostasis. Thromb Haemostas 1991; 66: 123-32.

14. Olson TS, Shore JD. Transient kinetics of heparin-catalyzed protease inactivation by antithrombin III. The reaction step limiting heparin turnover in thrombin neutralization. J Biol Chem 1986; 261: 13151-9.
15. Lijnen HR, Hoylaerts M, Collen D. Heparin binding properties of human histidin-rich glycoprotein. Mechanism and role in the neutralisation of heparin in plasma. J Biol Chem 1983; 258: 3803-8.

16. Lijnen HR, van Hoef B, Collen D. Histidin-rich glycoprotein modulates the anticoagulant activity of heparin in human plasma. Thromb Haemostas 1984; 51: 266-8.

17. Lane DA, Pejler G, Flynn AM, Thomson EA, Lindah1 U. Neutralisation of heparin related saccharides by histidin-rich glycoprotein and platelet factor 4. J Biol Chem 1986; 261: 7387-92.

18. Hemker HC, Béguin $S$. The mode of action of heparins in plasma in vivo and in vitro. In: Heparin and related polysaccharides. Lindahl U, Lane D, eds. Plenum Publishing Corporation 1992, pp 221-30.

Received January 6, 1992 Accepted after revision March 25, 1992

\section{ANNEXE}

An Improved Algorithm for the Calculation of Prothrombinase Activity

H. Kessels, G. M. Willems, H. C. Hemker

\section{Prothrombinase Activity}

The rate of change $(V)$ of the thrombin concentration $(T)$ in plasma is defined by the rate of thrombin formation (prothrombinase activity, $P$ ) and the rate of thrombin breakdown $(D)$ :

$V(t)=\mathrm{d} T / \mathrm{d} t=P(t)-D(t)$.

$V(t)$ can be obtained from the measured course of the amidolytic activity. $D(t)$ is determined from the independently measured thrombin decay constants and the thrombin concentration $T(t)$. The prothrombinase activity $P(t)$ is then calculated by summing $D(t)$ and $V(t)$ for each time point.

\section{Thrombin Concentration}

The experimentally determined amidolytic activity $E_{i}$ at time point $t_{i}$ reflects the thrombin concentration $T_{i}$ at this point and the concentration of the alpha ${ }_{2}$-macroglobulin-thrombin complex $\mathrm{MT}_{i}$ at time $t_{i}$ :

$E_{i}=T_{i}+f \mathrm{MT}_{i}$

Since the $\alpha_{2}$ M-thrombin complex has not the same activity towards the chromogenic substrate $\mathrm{S} 2238$ as free thrombin, a factor $f$ is necessary. The value of $f$ has been determined to be 0.556 .

\section{Thrombin Decay}

Thrombin in a plasma is inhibited by a number of serine protease inhibitor proteins $I$, giving rise to an essentially irreversible complex $C$ :

$T+I \stackrel{k}{\rightarrow} C$.

The rate of formation of $C$ is then given by

$\mathrm{d} C / \mathrm{d} t=-\mathrm{d} l / \mathrm{d} t=k I(t) T(t)$.

Serine protease inhibitors relevant to thrombin breakdown in plasma are Antithrombin III $(A), \alpha_{2}$-Macroglobulin $(M)$, Heparin Cofactor II $(H)$, and a number of serpins with a relatively unimportant anti-thrombin activity $(R)$. The concentration of $\alpha_{2} \mathrm{M}$ $(M)$ does not decrease significantly during coagulation, nor does the concentration of the group of inhibitors of secondary importance $(R)$. Therefore, it is reasonable to assume first order kinetics 
for the inactivation of thrombin by these inhibitors:

$D(t)=\left[k_{1}{ }^{\prime} A(t)+k_{4}{ }^{\prime} H(t)+k_{2}+k_{3}\right] T(t)$

with $k_{2}=k_{2}^{\prime} M$ and $k_{3}=k_{3}{ }^{\prime} R$.

\section{Procedure}

In practice the course of amidolytic activity is measured at discrete time points about $30 \mathrm{~s}$ apart. The rate of change of the thrombin concentration at time $i-1$ is estimated as the average rate of change between time $i-1$ and time $i$ :

$V_{i-1}=\left(T_{i}-T_{i-1}\right) /\left(t_{i}-t_{i-1}\right)$.

Values of the first-order decay constants for thrombin due to $\alpha_{2} \mathrm{M}$ and due to minor inhibitors, and of the second-order decay constants for thrombin due to AT III and HC II are measured in separate experiments. Prothrombinase calculations are then carried out by a computer program according to the following pseudo code:

an array $E$ contains the measured amidolytic activities an array $t$ contains the timepoints of measurement of these amidolytic activities

$A_{0}$ : user input

$H_{0}$ : user input

$\mathrm{MT}_{0}=0$

$\mathrm{RT}_{0}=0$

$T_{0}=0$

$k_{1}{ }^{\prime}, k_{2}, k_{3}, k_{4}{ }^{\prime}$ : user input

for $i=1$ to number-of-points do

begin

$\Delta t=t_{i}-t_{i-1}$

$\mathrm{MT}_{i}=\mathrm{MT}_{i-1}+k_{2} * T_{i-1} * \Delta t$

$\mathrm{RT}_{i}=\mathrm{RT}_{i-1}+k_{3} * T_{i-1} * \Delta t$

$A_{i}=A_{i-1}-k_{1}^{\prime} * A_{i-1} * T_{i-1} * \Delta t$

$H_{i}=H_{i-1}-k_{4}{ }^{\prime} * H_{i-1} * T_{i-1} * \Delta t$

$T_{i}=E_{i}-f * \mathrm{MT}_{i}$

$V_{i-1}=\Delta T / \Delta t=\left(T_{i}-T_{i-1}\right) / \Delta t$

$D_{i-1}=\left(k_{1}{ }^{\prime} * A_{i-1}+k_{2}+k_{3}+k_{4}{ }^{\prime} * H_{i-1}\right) * T_{i-1}$

$P_{i-1}=V_{i-1}+D_{i-1}$

$O_{i}=T_{i}+\mathrm{MT}_{i}+\mathrm{RT}_{i}+A_{0}-A_{i}+H_{0}-H_{i}$

end.
The arrays and variables used represent the following quantities

$T$ : thrombin concentration

$E$ : experimentally determined amidolytic activity

A: AT III concentration

H: HC II concentration

MT: $\alpha_{2}$ M-thrombin-complex concentration

RT: other-inhibitors-thrombin-complex concentration

$V$ : delta of thrombin concentration

$D$ : velocity of thrombin decay

$P$ : velocity of thrombin formation (prothrombinase activity)

$O$ : quantity of prothrombin converted

$t:$ time

$k_{1}$ ', $k_{4}$ ': second-order decay constants for AT III and HC II $k_{2}, k_{3}$ : first-order decay constants for $\alpha_{2} \mathrm{M}$ and Rest

\section{Estimation of the $\alpha_{2}$ Macroglobulin Dependent Decay Constant}

Since the complex of $\alpha_{2} \mathrm{M}$ and thrombin has residual amidolytic activity, the $\alpha_{2} \mathrm{M}$ dependent decay constant $k_{2}$ can be estimated directly from thrombin generation curves. First, thrombin concentrations are calculated from amidolytic activities using a range of values $\kappa$ for $f k_{2}$. These calculated thrombin concentration $T_{\kappa}$ are related to the real (but unknown) thrombin concentrations $T$ in the following manner:

$T_{\mathrm{\kappa}}(t)=T(t)+\left(f k_{2}-\kappa\right) \int_{0}^{t} \mathrm{e}^{-\kappa(t-s)} T(s) \mathrm{d} s$.

If it is assumed that prothrombin conversion has stopped at a timepoint $t_{0}$ then

$T(t)=T\left(t_{0}\right) \mathrm{e}^{-\left(k_{1}+k_{2}\right)\left(t-t_{0}\right)}, \quad t \geqslant t_{0}$.

If it is further assumed that $T(t)=0$ after $t_{0}$, and that $k_{1}+k_{2} \gg \kappa$, then it follows from (I) and (II) that:

$T_{\mathrm{\kappa}}(t) \approx\left(f k_{2}-\kappa\right) C \mathrm{e}^{-\kappa\left(t-t_{0}\right)}$

where $C$ is the following constant:

$C=\int_{0}^{t_{0}} \mathrm{e}^{-\kappa\left(t_{0}-s\right)} T(s) \mathrm{d} s$.

Thus, $T_{\kappa}(t) / \mathrm{e}^{-\kappa\left(t-t_{0}\right)}$ is a constant value for a given $\kappa$ after timepoint $t_{0} . T_{\kappa}(t) / \mathrm{e}^{-\kappa\left(t-t_{0}\right)}$ is then plotted as a function of $\kappa$, and $k_{2}$ is determined from the intersection of this function with the horizontal axis. 